\title{
Higher-level bee classifications (Hymenoptera, Apoidea, Apidae sensu lato) ${ }^{1}$
}

\section{Gabriel A. R. Melo ${ }^{2}$ \& Rodrigo B. Gonçalves ${ }^{2}$}

\author{
${ }^{1}$ Contribuition number 1534 of the Departamento de Zoologia, Universidade Federal do Paraná. \\ ${ }^{2}$ Departamento de Zoologia, Universidade Federal do Paraná. Caixa Postal 19020, 81531-980 Curitiba, Paraná, Brasil. \\ E-mail: garmelo@ufpr.br; rodrigocaderno@ufpr.br
}

\begin{abstract}
A higher-level classification of bees, in which the entire group is treated as a single family - the Apidae - is advocated here. A total of seven subfamilies, 51 tribes and 27 subtribes are recognized. These subfamilies correspond to the families adopted in the traditional classification. Although the proposed changes do not involve any major rearrangement, basically only changing the rank given to the main groups, the new system makes the classification of bees more consistent with that adopted for other major groups of aculeate Hymenoptera. It also departs from the $19^{\text {th }}$ century practice, perpetuated in the traditional classification, of giving family-status to the main groups of bees. A correspondence table associating the taxon names used in the current traditional classification with those of the revised classification is presented. Scrapterini new tribe (typegenus Scrapter Lepeletier \& Serville) is proposed to accommodate the southern African genus Scrapter. KEY WORDS. Aculeata, family-group names, bees, apoid wasps.
\end{abstract}

RESUMO. Classificação dos grandes grupos de abelhas (Hymenoptera, Apoidea, Apidae sensu lato). Apresenta-se uma classificação para as abelhas em que o todo o grupo é tratado como uma única família - Apidae. São reconhecidas sete subfamílias, 51 tribos e 27 subtribos. As subfamílias correspondem às famílias da classificação tradicional. Apesar das mudanças propostas afetarem apenas o status dos grupos, o novo sistema torna a classificação das abelhas mais consistente com aquela adotada para os grandes grupos de Hymenoptera aculeados. Além disso, distancia-se da tradição de dar status de família aos grupos principais de abelhas, uma prática do século 19 perpetuada na classificação tradicional. É apresentada uma tabela de correspondência associando os nomes dos táxons usados na classificação tradicional corrente com aquelas da classificação sendo proposta aqui. Scrapterini tribo nova (gênero-tipo Scrapter Lepeletier \& Serville) é proposta para acomodar Scrapter, um gênero restrito à porção sul do continente africano.

PALAVRAS CHAVE. Aculeata, nomes do grupo-de-família, abelhas, vespas apóideas.

Bees are among the insect groups most intensively studied, with a vast amount of information published about them each year. As for any other group of organisms, the retrieval of this information is dependent on a classification, whose stability, in terms of denomination and scope of the names, is critical for proper communication. Despite this crucial practical purpose of classifications, they should not be seen as immutable. Besides the desired adjustments derived from robust phylogenetic analyses, a given group should have a classification consistent with that applied to the remaining members of the larger group to which it belongs.

The current classification of the aculeate Hymenoptera places the bees, together with a few other wasp families (the apoid wasps), in the superfamily Apoidea (Brothers 1999, Melo 1999). The current most widely used classification for bees
(Michener 2000) divides them in a number of taxa at the familylevel. Although clearly monophyletic (Alexander \& Michener 1995, Melo 1999), the bees as a group have no formal rank name in the current classification employed by the melittologists. Some refer to the whole group as the 'Apiformes', an informal division of the Apoidea introduced by Brothers (1975).

In order to have a formal rank name for bees as a whole and to make their classification more compatible with the higher-level system employed for the aculeate Hymenoptera, advocated here is a classification in which all bees are included in only one family, the Apidae. This proposal is not new and has been introduced by previous authors (e.g. GAULD \& BolToN 1988, GRIswold et al. 1995). Differently from Griswold et al. (1995) and similarly to GAULD \& BolTon (1988), the subfamilies here have a strict correspondence with the families of the tra- 
ditional classification. The changes introduced were kept to a minimum in order to cause as little disruption as possible to the current and most widely used system. Most tribes of the traditional classification were maintained under the same scope.

\section{The current traditional classification}

The modern higher-level classification for bees was introduced with Michener's (1944) work. Six families were then recognized in his system: Andrenidae, Apidae, Colletidae, Halictidae, Megachilidae and Melittidae. It represented an important advancement over previous classifications in that it was based on a large number of characters, classified the cleptoparasitic groups more naturally and recognized a smaller number of families. A more detailed comparison between Michener's (1944) classification and those available in the first half of the last century can be found in Michener (2000). Also, this work should be consulted by those interested in an account on the history of bee classifications, in particular those classificatory systems proposed before Michener (1944).

The higher-level classification currently favored by melittologists (e.g. Michener 2000) differs very little from that proposed in Michener (1944). Seven families are adopted, six of them from the 1944 system plus the Stenotritidae. Only a few more significant changes were introduced, as for example the position of the Fideliinae (transferred from the Apidae to the Megachilidae), the Stenotritidae (then a subfamily of the Colletidae and now a family on its own) and the Ctenoplectrini (considered part of the Melittidae and now a tribe of the Apidae). The basis for these major classificatory changes was provided mainly by the phylogenetic analyses presented in Roig-Alsina \& Michener (1993) and AleXander \& Michener (1995).

Michener's system adopts the categories of subfamily and tribe for the major divisions within each of his bee families. The categories of supertribe and subtribe have not been employed. The seven families of Michener's (2000) classification are split in a total of 21 subfamilies (see Tab. I). There are four subfamilies in Andrenidae, three in Apidae, five in Colletidae, four in Halictidae, two in Megachilidae and three in Melittidae (except for its two genera, the family Stenotridae has no subdivisions). These subfamilies are further subdivided into 53 tribes [the two tribes of Michener's (2000) Xeromelissinae were omitted; see Michener \& Rozen (1999)]. The number of tribes within each subfamily is quite heterogeneous. No tribes are recognized in 12 subfamilies, while the Apinae alone contains 19 tribes.

\section{Alternative classifications}

Although Michener's classification is amply used in the melittological literature, as well as in major revisionary works on the Hymenoptera (e.g. Goulet \& Huber 1993), a few alternative higher-level systems have been proposed. Among modern authors, GAULD \& BolTON (1988), in their introductory book to the order Hymenoptera, were the first to oppose strongly the current treatment given to bees. They criticized the traditional classification for recognizing a number of families that were seen as equivalent, in distinctness, to subfamilies in other families of Apocrita. In their work, the bees were regarded as constituting a single family, the Apidae, with the families of the traditional classification treated as subfamilies. These authors did not present a complete system for all higher-level categories.

Before Gauld \& Bolton (1988), only a few authors, usually non-melittologists, have used the name Apidae to refer to the bees as whole (e.g. BEAUMONT 1964, LOMHOLDT 1982). Unfortunately, GAULD \& BolTon's proposal did not gain wide acceptance among melittologists. Most authors continued employing the traditional classification, with very few exceptions (e.g. Griswold et al. 1995, GRIMALdi 1999). Griswold et al. (1995), in a book chapter revising the bee fauna of Costa Rica, refer to bees as a single family, but differently from GAULD \& BOLTON (1988), they did not reduce the rank of the traditional families to subfamilies. Instead, they maintained all the subfamilies of the traditional classification, leaving unnamed the fundamental major groups in bee taxonomy, i.e. the families of MicheneR's system. Their proposal clearly represents a poor alternative to the traditional classification and is unlikely to be followed by other melittologists.

More recently, MeLo (1999) proposed a higher-level classification for the superfamily Apoidea, based on phylogenetic analyses involving the major lineages of the entire group, recognizing four wasp families - Ampulicidae, Heterogynaidae, Sphecidae and Crabronidae - and a single bee family - Apidae. Under this system, the bees are given an equivalent rank to the other subgroups within the Apoidea. This author also argued that the informal divisions of the Apoidea, the Apiformes (bees) and Spheciformes (wasps), introduced by BRotHers (1975) should be abandoned, since the Spheciformes are clearly paraphyletic in relation to the Apiformes.

BRothers (1999), in his review on the classification of the aculeate Hymenoptera, has argued in favor of MeLo's classification. He considered that the opposite approach, i.e. extending MiCHENER's system to the apoid wasps (as done by FinNAMORE \& Michener 1993), would require recognition of an unnecessary high number of families (about 17), many of them difficult to diagnose by non-experts in the group. BROTHERs cites the ants as an example in which the use of the single family Formicidae for them, despite the diversity of the group, recognizes the 'functional similarities amongst its members'. Incorporating Melo's proposal, BRothers (1999) presented the following higher-level system for the Aculeata: superfamily Chrysidoidea, containing the families Plumariidae, Scolebythidae, Bethylidae, Chrysididae, Sclerogibbidae, Dryinidae and Embolemidae; superfamily Apoidea, with Heterogynaeidae, Ampulicidae, Sphecidae, Crabronidae and Apidae; superfamily Vespoidea, with Sierolomorphidae, Tiphiidae, Sapygidae, Mutillidae, Pompilidae, Rhopalosomatidae, Bradynobaenidae, Formicidae, Vespidae and Scoliidae. 
Table I. Correspondence table between taxon names used in the traditional classification (MICHENER 2000) and in the revised classification proposed here. Authorship for family-group names according to MiCHENER $(1986,1997)$ and EnGel $(1999)$.

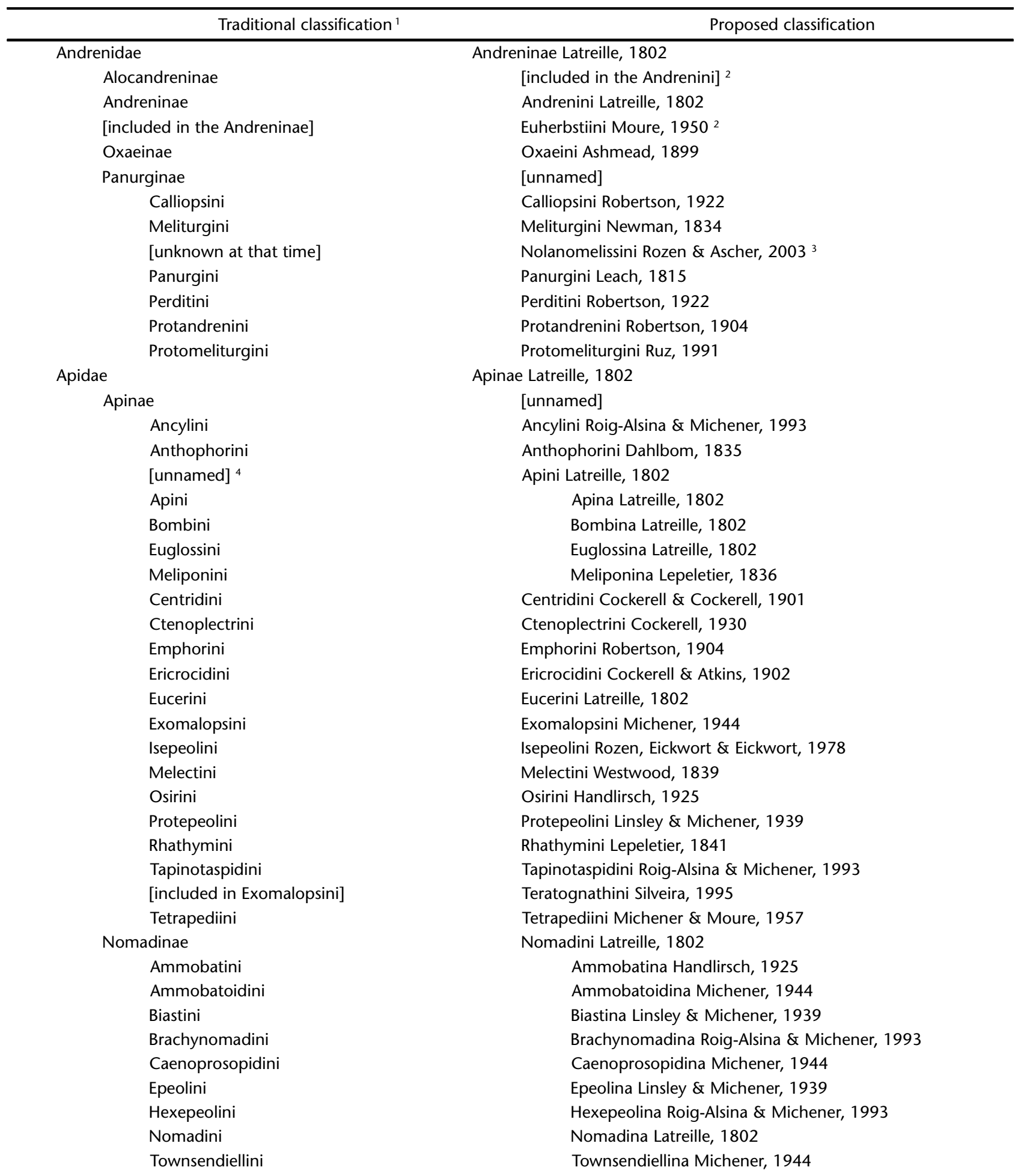


Table I. Continued.

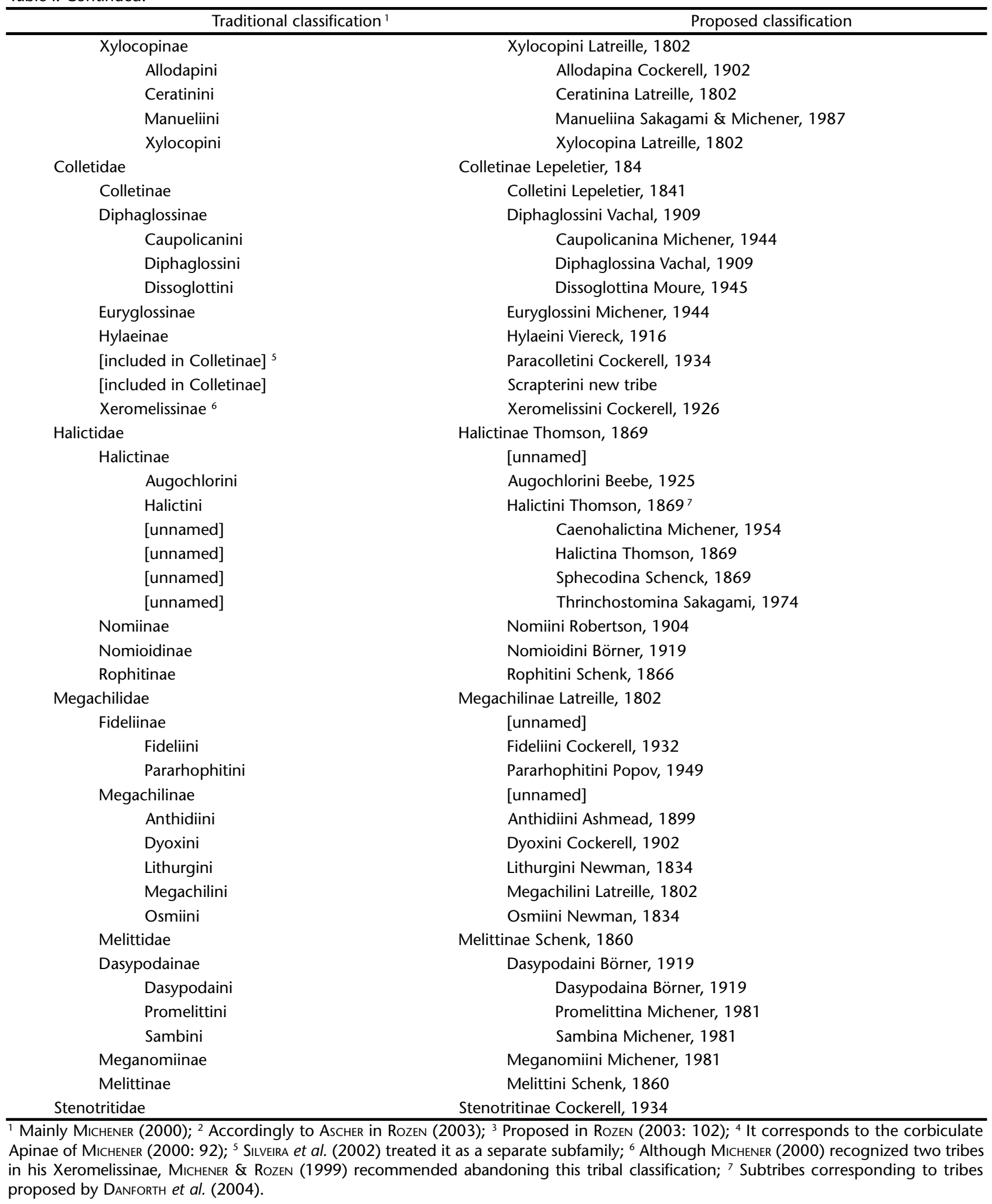

Revista Brasileira de Zoologia 22 (1): 153-159, março 2005 


\section{A revised higher-level classification of bees}

Here a step further is taken to present a complete higherlevel classification of bees, in which the whole group is treated as one family, the Apidae. It is divided into seven subfamilies corresponding to the traditional families adopted in Michener's classification. The right column of table I presents this revised classification of bees. A total of seven subfamilies, 51 tribes and 27 subtribes are recognized.

Most of Michener's subfamilies were simply given the status of tribe. In the case of traditional subfamilies containing no tribes, this was a straightforward change. For subfamilies with tribes, however, two alternative procedures were adopted: (1) the subfamily was made a tribe and its tribes changed to subtribes (e.g. Michener's Diphaglossinae and Xylocopinae); (2) the taxon corresponding to the subfamily was left unnamed and its tribes were kept under the same status (e.g. Michener's Apinae and Panurginae). An alternative procedure could have been treating these groups as supertribes, in order to have names for all taxa of the traditional classification and, at the same time, to maintain the tribes unchanged. It was opted, however, not to introduce a category that has not previously been used in bee taxonomy, although recognizing that it might be convenient, at some point, to have these groups treated as supertribes.

Having unnamed groups might be considered a very undesirable feature in classifications. It should be pointed out, on the other hand, that classifications serve mainly practical purposes, with names being used only to point out relevant or biologically interesting clades. Naming every branch postulated in a phylogenetic tree can bring an unnecessary burden to the classifications. Many of these names would also likely be disputed every time a new phylogenetic hypothesis is proposed for the group.

The higher-level classification discussed here is taken mostly from Michener's (2000) revision. The sources of a few additional names are indicated in table I. The classification for extant groups introduced by ENGEL (2001), with addition of several higher-level taxa not present in Michener's system, will not be discussed here, since that author did not present proper phylogenetic analyses to back it up. Also, the classification discussed here is restricted to extant groups. Those interested in familygroup names applied to fossil taxa should refer to ENGEL (2001).

Although the proposed changes in the higher-level classification of bees do not involve any major rearrangement, basically only changing the rank given to the main groups, the new system makes the classification of bees more consistent with that adopted for other major groups of aculeate Hymenoptera. It also departs from the $19^{\text {th }}$ century tradition, perpetuated in Michener's classifications, of giving family-status to the major groups of bees.

Below the changes introduced within each of the bee subgroups, i.e. subfamilies, are commented. In order to avoid confusion and unless otherwise indicated, the taxon names mentioned below refer to the status here proposed. Taxon names from the traditional classification are always pointed out as such.

\section{Andreninae}

No tribes are recognized within Michener's Alocandreninae, Andreninae and Oxaeinae, therefore reducing them to tribes is straightforward. The situation is more problematic in relation to Michener's Panurginae. Despite demonstrating the monophyly of Michener's Panurginae, recent molecular analyses by Ascher (in Rozen 2003) have shown that the traditional scope of the group and its subdivisions, i.e., its tribal classification, are somewhat incongruent with the molecular data. For example, the Protandrenini sensu Michener is not monophyletic, as the genus Neffapis Ruz comes out as separate clade. Also, the new taxon of andrenine bees proposed in Rozen (2003), the Nolanomelissini Rozen \& Ascher, was included as a tribe in their expanded Panurginae, although it could have as well been given subfamily status. Therefore, Michener's Panurginae is left here without a formal name, but keeping its tribes unchanged.

\section{Apinae}

Two of the three subfamilies of Michener's Apidae are reduced to tribes, the Xylocopini sensu lato and the Nomadini sensu lato. Their subgroups are here treated as subtribes. In the case of Michener's Apinae, instead of simply reducing it to tribe, it is decided to leave it unnamed, keeping all the tribes included in this group by MiCHENER (2000). This more cautious position is taken here under the expectation that future work might support a different arrangement for the major groups within the Apinae, especially when considering that the evidence for monophyly of Roig-Alsina \& Michener's (1993) Apinae is rather weak (see also Michener 2000).

\section{Colletinae}

Alexander \& Michener (1995) recognized five subfamilies within their Colletidae, a classification followed by MichenER (2000). These authors were somewhat conservative in that their phylogenetic results were not strictly followed when revising the classification within their Colletidae. Although lacking evidence for monophyly of their Collletinae, Alexander \& Michener (1995) decided to recognize this taxon. The remaining four major groups had their monophyly well corroborated. These groups are here treated as tribes: Diphaglossini, Euryglossini, Hylaeini and Xeromelissini (Tab. I).

Three additional tribes are recognized here to accommodate the taxa included in AleXANder \& Michener's Colletinae. The first is Colletini sensu stricto, for the genus Colletes Latreille, 1802 and closest relatives from South America. The second is Paracolletini, containing all the groups in Michener's (1989) Paracolletini, except Scrapter. The third tribe is the Scrapterini, new tribe (type-genus Scrapter Lepeletier \& Serville), here proposed to accommodate Scrapter, a genus restricted to southern Africa. In some of Alexander \& Michener's (1995) analyses, Scrapter was clearly associated with the clade formed by Hylaeini + Xeromelissini. Considering the diversity within the genus (EARDley 1996, Michener 2000), further revisions could break it into smaller groups with genus-level status. The iso- 
lated position of Scrapter, in relation to the Paracolletini, was also reinforced by the results, based on molecular data, obtained by BRADY \& DANForTh (2004).

\section{Halictinae}

Based on their morphological phylogenetic analyses, AlEXANDER \& Michener (1995) recognized four subfamilies in their Halictidae. This same arrangement was also recovered in a recent molecular analysis by DANFORTH et al. (2004). These latter authors went further and subdivided MicheneR's Halictini into four tribes, leaving the entire group unnamed. Here the subfamilies of Michener's Halictidae are given tribal status, except his Halictinae, which is left unnamed. Its two tribes, Halictini and Augochlorini, are kept under the same status. The Halictini is further subdivided, following DANFORTH et al. (2004); the subgroups are, however, treated here as subtribes (Tab. I).

\section{Megachilinae}

Roig-Alsina \& Michener (1993) divided their megachilids in two subfamilies and six tribes. Only their six tribes are kept here. The higher classification of the Megachilinae is likely to change in the future considering that the Osmiini might be paraphyletic in relation to the Megachilini (Michener 2000).

\section{Melittinae}

The results obtained by Alexander \& Michener (1995) led them to split the traditional Melittidae into three separate families. Michener (2000) revised this classification and kept again these three taxa under only one family name. Here Michener's subfamilies are simply given tribal status. The three subgroups of Dasypodaini are treated as subtribes.

\section{Stenotritinae}

This group contains only two genera from Australia. In Alexander \& Michener's (1995) analyses, it appeared as the most basal bee lineage or grouped either with the Colletinae or the Andreninae. A closer relationship with the Colletinae seems less likely after the results obtained by Brady \& Danforth (2004) showing that the gene for the elongation factor- $1 \alpha$ in the Colletinae possess an unique intron, which is absent from Stenotritus. Morphological features, such as the double subantennal sutures (AlEXANDER \& Michener 1995) and the reduced sting apparatus (PACKER 2003), suggest a closer relationship with the Andreninae.

\section{ACKNOWLEDGMENTS}

We thank Eduardo A. B. Almeida, Fernando Zanella and James Carpenter for their comments and suggestions to the manuscript. GARM has been supported by a fellowship from CNPq (303125/2003-9) and RBG by a PIBIC scholarship from CNPq/UFPR.

\section{REFERENCES}

Alexander, B.A. \& C.D. Michener. 1995. Phylogenetic studies of the families of short-tongued bees (Hymenoptera: Apoidea).
University of Kansas Science Bulletin, Lawrence, 55: 377 424.

Beaumont, J. 1964. Insecta Helvetica Fauna 3. Hymenoptera: Sphecidae. Laussane, Société Entomologique Suisse, 169p.

Brady, S.G. \& B.N. Danforth. 2004. Recent intron gain in elongation factor-1a of colletid bees (Hymenoptera: Colletidae). Molecular Biology and Evolution, Oxford, 21: 691696.

Brothers, D.J. 1975. Phylogeny and classification of the aculeate Hymenoptera, with special reference to the Mutillidae. University of Kansas Science Bulletin, Lawrence, 50: 483648.

BRothers, D.J. 1999. Phylogeny and evolution of wasps, ants and bees (Hymenoptera, Chrysidoidea, Vespoidea and Apoidea). Zoologica Scripta, Oslo, 28: 233-249.

Danforth, B.N.; S.G. Brady; S.D. Sipes \& A. Pearson. 2004. Singlecopy nuclear genes recover Cretaceous-age divergences in bees. Systematic Biology, Philadelphia, 53: 309-326.

EARDLey, C.D. 1996. The genus Scrapter Lepeletier \& Serville. African Entomology, Hatfield, 4: 37-92.

ENGEL, M.S. 1999. Augochlorini Beebe, 1925 (Insecta, Hymenoptera): corrected authorship and date (not Moure, 1943). Bulletin of Zoological Nomenclature, London, 56: 198.

ENGEL, M.S. 2001. A monograph of the Baltic amber bees and evolution of the Apoidea (Hymenoptera). Bulletin of the American Museum of Natural History, New York, 259: 1192.

Finnamore, A.T. \& C.D. Michener. 1993. Superfamily Apoidea, p. 279-357. In: H. Goulet \& J.T. Huber (Eds). Hymenoptera of the world: an identification guide to families. Ottawa, Agriculture Canada, 668p.

Gauld, I.D. \& B. Bolton. 1988. The Hymenoptera. Oxford, Oxford University Press, 332p.

Goulet, H. \& J.T. Huber. 1993. Hymenoptera of the world: an identification guide to families. Ottawa, Agriculture Canada, 668p.

Grimaldi, D. 1999. The co-radiations of pollinating insects and angiosperms in the Cretaceous. Annals of the Missouri Botanical Garden, Saint Louis, 86: 373-406.

Griswold T.; F.D. Parker \& P.E. Hanson. 1995. The bees (Apidae), p. 650-691. In: P.E. Hanson \& I.D. Gauld (Eds). The Hymenoptera of Costa Rica. Oxford, Oxford University Press, 893p.

LomHoLDT, O. 1982. On the origin of bees (Hymenoptera: Apidae, Sphecidae). Entomologica Scandinavica, Copenhagen, 13: 185-190.

Melo, G.A.R. 1999. Phylogenetic relationships and classification of the major lineages of Apoidea (Hymenoptera), with emphasis on the crabronid wasps. Scientific Papers, Natural History Museum of the University of Kansas, Lawrence, 14: $1-55$.

Michener, C.D. 1944. Comparative external morphology, 
phylogeny, and a classification of the bees (Hymenoptera). Bulletin of the American Museum of Natural History, New York, 82: 151-326.

Michener, C.D. 1986. Family-group names among bees. Journal of the Kansas Entomological Society, Lawrence, 59: 219234.

Michener, C.D. 1989. Classification of American Colletinae (Hymenoptera, Apoidea). University of Kansas Science Bulletin, Lawrence, 53: 622-703.

Michener, C.D. 1997. Genus-group names of bees and supplemental family-group names. Scientific Papers, Natural History Museum of the University of Kansas, Lawrence, 1: 1-81.

Michener, C.D. 2000. The Bees of the World. Baltimore, Johns Hopkins University Press, 913p.

Michener, C.D. \& J.G. Rozen. 1999. A new ground-nesting genus of xeromelissine bees from Argentina and the tribal classification of the subfamily (Hymenoptera: Colletidae).
American Museum Novitates, New York, 3281: 1-10.

PACKer, L. 2003. Comparative morphology of the skeletal parts of the sting apparatus of bees (Hymenoptera: Apoidea). Zoological Journal of the Linnean Society, London, 138: $1-38$.

Roig-Alsina, A. \& C.D. Michener. 1993. Studies of the phylogeny and classification of long-tongued bees (Hymenoptera: Apoidea). University of Kansas Science Bulletin, Lawrence, 55: 123-173.

Rozen, J.G. 2003. A new tribe, genus, and species of South American panurgine bee (Andrenidae, Panurginae), oligoletic on Nolana (Nolanaceae), p. 93-108. In: G.A.R. Melo \& I. AlvesDos-SAntos (Eds). Apoidea Neotropica: homenagem aos 90 anos de Jesus Santiago Moure. Criciúma, Editora UNESC, $320 p$.

Silveira, F.A.; G.A.R. Melo \& E.A.B. Almeida. 2002. Abelhas brasileiras: sistemática e identificação. Belo Horizonte, F.A. Silveira, 253p.

Received in 05.VIII.2004; accepted in 26.I.2005. 